Brit.F. industr. Med., 1967, 24, 213.

\title{
A Cooling System for Impermeable Clothing
}

\author{
J. P. GLEESON and J. F. PISANI \\ From the Australian Defence Scientific Service, Department of Supply, Defence Standards Laboratories, \\ Maribyrnong, Victoria, Australia
}

A self-contained conditioning unit for use with impermeable protective clothing is described.

The pack-mounted unit weighing $10 \mathrm{lb}$. $(4.5 \mathrm{~kg}$.) will enable a wearer to work for approximately one hour at temperatures in the zone of evaporative regulation.

At $40 \cdot 6^{\circ} \mathrm{C}$. ( $\left(105^{\circ} \mathrm{F}\right.$.), the temperature at which the unit was tested, the heat load imposed by the complete assembly of suit, conditioning unit, and ducting is only slightly higher than that imposed by the wearing of shorts.

Christie, Gleeson, Jowett, and Wright (1957) measured how effectively ambient air could be used to ventilate impermeable protective clothing and relieve heat stress when the clothing was worn in chamber environments simulating desert and tropical climates. While this form of ventilation extended the time a man could work in an impermeable suit, thermal equilibrium could not be maintained as the external temperature approached body temperature. Though ventilation rates ranged from 5 to $15 \mathrm{ft}^{3}$ ( 140 to 422 1.) of air per minute some heat storage had to be accepted. From this work it seemed that a self-contained suit, ventilated by a bellows of practical dimensions, could cope only with climates near an effective temperature of $28 \cdot 3^{\circ} \mathrm{C}$. $\left(83^{\circ} \mathrm{F}\right.$.) over a working period of one to two hours.

Other devices designed to alleviate heat stress in operators wearing protective clothing have been described. The Farnborough group, whose interest is in protecting pilots of high performance aircraft, have reported their results with water-conditioned and air-ventilated suits (Burton, 1965). Here the problem is simpler as the subject is stationary and seated close to the source of cooling fluid.

Another cooling system for impermeable clothing, which is simple and effective in low ambient humidity, is the 'wetted over garment' pioneered by Crowden (1938). His subjects wore respirators and heavy oilskins (decontamination clothing) over service uniforms, and over the oilskins wetted fabrics, ranging from loose, heavy towelling to a thin attached facing-layer. The subjects so clad

Received for publication November 22, 1966. completed moderate work in comfort with an air temperature of $32 \cdot 2^{\circ} \mathrm{C}$. $\left(90^{\circ} \mathrm{F}\right.$.) and relative humidities $(\mathrm{RH})$ up to $65 \%$. With humidities much higher than this, evaporation from the wetted layer was insufficient to provide relief.

Another principle which has been used successfully in industry is that of a flexible attached airline, delivering large volumes of conditioned or dry air. As it is difficult to design an air hose combining adequate insulation and flexibility, the supplied cool air may become heated before it reaches the operator. This effect can be offset by using a permeable air hose so that the escaping air insulates the air fed to the suit. An extension of this principle is the 'dynamically insulated' permeable suit where the supplied air escapes radially and cools more efficiently than if it flowed laterally over the wearer's body (Crockford and Hellon, 1964). There are two disadvantages of this type of protection: power requirements are high, and the trailing air line limits the mobility of the wearer.

Simple calculations (see Appendix, p. 218) show that the volume of air at $35^{\circ} \mathrm{C}$. and $40 \% \mathrm{RH}$ required to maintain thermal equilibrium is of the order of $\mathrm{r} \mathrm{ft}^{3} / \mathrm{min}$. (368 $1 . / \mathrm{min}$.). If the air is dry $(0 \% \mathrm{RH})$ the volume is reduced by about half but is still beyond the capacity of a compact and portable air source. We were therefore led to consider a refrigerant; liquid air being completely dry and having a specific volume of $1 \cdot 161 . / \mathrm{kg}$. ( 32 in. ${ }^{3} / \mathrm{lb}$.) at $-190^{\circ} \mathrm{C}$. was particularly attractive.

Air from this source can serve the double purpose of cooling the air in the space between the suit and the wearer, and drying it by condensing the evaporated sweat. A functional protective coverall using 


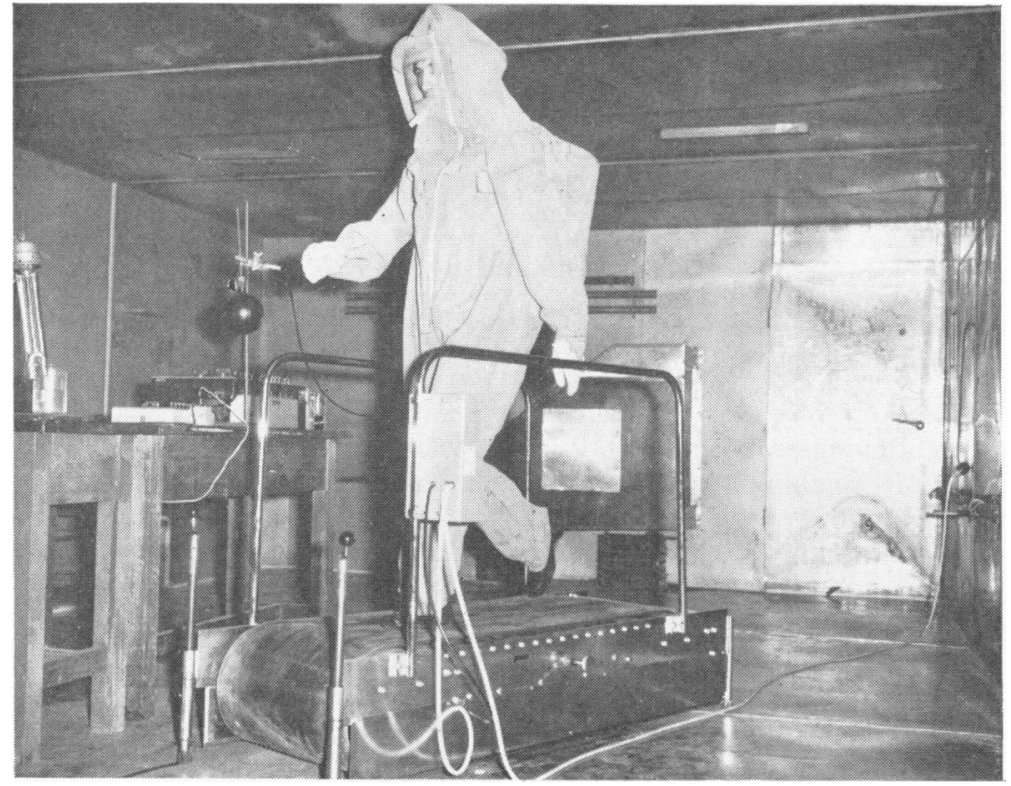

FIG. I. General view of coverall under test.

this principle has been designed and described (Gleeson, 1961; Gleeson and Hicks, 1963).

More recently, the cooling unit has been redesigned and the improved assembly (Fig. I) briefly described (Anon., I965). It should be stressed that the present cooling system is not intended to protect against very high ambient temperature, as is Crockford and Hellon's, but to remove excess body heat when the suit is worn in the zone of evaporative regulation (Winslow and Herrington, 1949). Basically the process involves evaporating a quantity of air from an insulated tank of liquid air, warming it by heat from the wearer's body, and passing it through a heat exchange chamber in the tank to evaporate more air and continue the cycle.

\section{Design}

Liquid air provides cooling (a) from its latent heat of vaporization, $(b)$ from its thermal capacity in coming to body temperature, and $(c)$ by its unsaturation with respect to water. In changing from liquid at $-190^{\circ} \mathrm{C}$. to gas at $35^{\circ} \mathrm{C}$. and $100 \%$ RH, 5 lb. (2.2 kg.) of liquid air absorb about $240 \mathrm{kcal}$. and thereby can provide cooling for approximately one hour (see Appendix, p. 218).

Care is needed in distributing the cool vapour, initially at about $-190^{\circ} \mathrm{C}$., throughout the suit space without causing cold spots or pockets of warm saturated air. In the design described below, these faults have been minimized. Circulating fans or pumps, which would impose additional power, weight, and space penalties, have been avoided.

The cooling system is shown in Figure 2.

The liquid air tank, $15 \times 20 \times 30 \mathrm{~cm}$. externally, is of double-walled sheet metal enclosing a sandwiched layer of polystyrene foam $2.5 \mathrm{~cm}$. thick. The second heat exchanger is built into the tank. Two foam rubber tubes, $2.5 \mathrm{~cm}$. O.D., $0.6 \mathrm{~cm}$. I.D., from the tank are brought over the shoulders to the first heat exchanger, which consists of a pair of rubberized fabric envelopes covering the chest and extending to the waist. For extra protection, $2.5 \mathrm{~cm}$. spacers of polyurethane foam separate the heat exchange envelopes from both the wearer and the suit. The foam rubber tubes protect the wearer from the cold air which evaporates from the tank and expands into the large envelopes where it becomes warm, at the same time cooling the adjacent suit space. This cooling, by stimulating convective air movement within the suit space, increases the wearer's comfort. As more liquid air evaporates, the pressure of vapour forces the warmed air from the envelopes towards the second heat exchanger in the tank. Here the air is recooled and, in giving up its heat, evaporates more liquid to continue the cycle, then passes through a set of five tubes leading to wrists, ankles and head where it is released into 


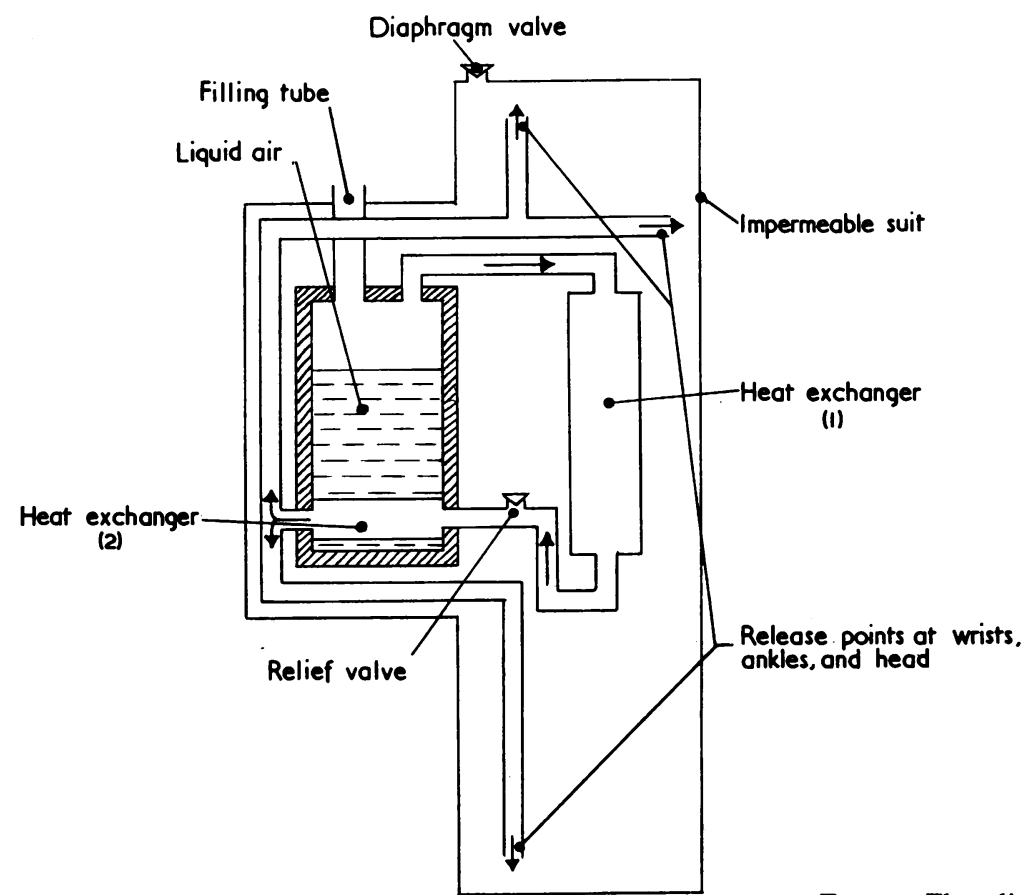

Fig. 2. Flow diagram of cooling system.

the suit. Finally the air, now warmed and moist, escapes from the suit through a diaphragm valve behind the wearer's head. An adjustable relief valve in the line between the two heat exchangers maintains constant pressure and regulates the rate of cooling by allowing surplus air to escape into the suit space. The spring tension of the relief valve, and hence the cooling rate, can be varied by a control knob outside the suit near the right hip.

\section{Experimental}

The degree of comfort provided by the cooling unit was tested by comparing the heat stress experienced by a subject in three different sets of clothing. Work output and chamber temperatures were the same for the three trials. The three clothing assemblies chosen were as follows:

(I) cotton underwear, shorts, sandshoes, and socks;

(2) an unventilated overall of PVC with elasticized cuffs and ankles, worn over cotton drawers, socks, and sandshoes. The assembly included rubber gloves and an aluminium helmet with plastic visor and skirt of PVC film draping on the shoulder. This was similar to the experimental suit described earlier (Christie et al., 1957);
(3) the cooled overall described above worn over cotton underwear and socks. Rubber gloves, boots, and headgear were welded to the suit, making a completely sealed enclosure weighing $9 \cdot \mathrm{I} \mathrm{kg}$. (20 lb.).

Subject The same subject, J.F.P., was used in all tests; age 23 years, height $180 \mathrm{~cm}$., weight $68.5 \mathrm{~kg}$.

Exercise A treadmill provided a convenient form of exercise, permitting the subject to walk without disturbing thermocouple attachments. Alternate five-minute periods of walking at $6 \mathrm{~km}$. $/ \mathrm{hr}$ and resting in a standing position gave a mean metabolic expenditure of about $210 \mathrm{kcal}$. per hour.

Biassed results due to possible acclimatization were minimized by spacing the tests over a long period of time; also by alternating the three sets of clothing so that any acclimatization would show up as a gradual change over the series of tests.

Environment The steel test chamber which has been described previously (Christie et al., 1957) was held at $40 \cdot 6^{\circ} \mathrm{C}$. (105 ${ }^{\circ} \mathrm{F}$.) measured by globe thermometer for all tests. Air movement was slight. Relative humidity was measured at intervals during control tests in which only shorts were worn (Table). 
TABLE

Temperature and Humidity of Chamber Air during Control Trials in Shorts

\begin{tabular}{|c|c|c|c|c|c|c|c|c|c|}
\hline \multirow{2}{*}{$\begin{array}{c}\text { Time } \\
(\text { min. })\end{array}$} & \multicolumn{3}{|c|}{ Wet Bulb Temperature $\left({ }^{\circ} \mathrm{C}.\right)$} & \multicolumn{3}{|c|}{ Dry Bulb Temperature $\left({ }^{\circ} \mathrm{C}.\right)$} & \multicolumn{3}{|c|}{ Relative Humidity (\%) } \\
\hline & Test $I$ & Test 2 & Test 3 & Test $I$ & Test 2 & Test 3 & Test $I$ & Test 2 & Test 3 \\
\hline o & $\begin{array}{c}23 \cdot 9 \\
(75 \cdot 0)^{1}\end{array}$ & $\begin{array}{c}22 \cdot 9 \\
(73 \cdot 2)\end{array}$ & $\begin{array}{c}23 \cdot 4 \\
(74 \cdot 1)\end{array}$ & $\begin{array}{c}40 \cdot 6 \\
(105 \cdot 1)\end{array}$ & $\begin{array}{c}40 \cdot 7 \\
(105 \cdot 3)\end{array}$ & $\begin{array}{c}40 \cdot 4 \\
(104 \cdot 7)\end{array}$ & 25 & 23 & 24 \\
\hline Io & $\begin{array}{c}24 \cdot 2 \\
(75 \cdot 6)\end{array}$ & $\begin{array}{c}23 \cdot 6 \\
(74 \cdot 5)\end{array}$ & $\begin{array}{c}23 \cdot 4 \\
(74 \cdot 1)\end{array}$ & $\begin{array}{c}40 \cdot 4 \\
(104 \cdot 7)\end{array}$ & $\begin{array}{c}40 \cdot 6 \\
(\operatorname{IO} \cdot 1)\end{array}$ & $\begin{array}{c}40 \cdot 6 \\
(105 \cdot I)\end{array}$ & 26 & 24 & 24 \\
\hline 20 & $\begin{array}{c}25 \cdot 1 \\
(77 \cdot 2)\end{array}$ & $\begin{array}{c}23 \cdot 6 \\
(74 \cdot 5)\end{array}$ & $\begin{array}{c}23 \cdot 6 \\
(74 \cdot 5)\end{array}$ & $\begin{array}{c}40 \cdot 5 \\
(104 \cdot 9)\end{array}$ & $\begin{array}{c}40 \cdot 6 \\
(\operatorname{I05} \cdot 1)\end{array}$ & $\begin{array}{c}40 \cdot 7 \\
(105 \cdot 3)\end{array}$ & 28 & 24 & 24 \\
\hline 30 & $\begin{array}{c}25 \cdot 1 \\
(77 \cdot 2)\end{array}$ & $\begin{array}{c}24 \cdot 0 \\
(75 \cdot 2)\end{array}$ & $\begin{array}{c}23 \cdot 8 \\
(74 \cdot 8)\end{array}$ & $\begin{array}{c}40 \cdot 5 \\
(104 \cdot 9)\end{array}$ & $\begin{array}{c}40.5 \\
(104.9)\end{array}$ & $\begin{array}{c}40.5 \\
(104.9)\end{array}$ & 29 & 25 & 24 \\
\hline 40 & $\begin{array}{c}25 \cdot 4 \\
(77 \cdot 7)\end{array}$ & $\begin{array}{c}24 \cdot 9 \\
(76 \cdot 8)\end{array}$ & $\begin{array}{c}23 \cdot 9 \\
(75 \cdot 0)\end{array}$ & $\begin{array}{c}40 \cdot 6 \\
(105 \cdot 1)\end{array}$ & $\begin{array}{c}40 \cdot 4 \\
(104 \cdot 7)\end{array}$ & $\begin{array}{c}40.5 \\
(104.9)\end{array}$ & 30 & 28 & 25 \\
\hline 50 & $\begin{array}{c}25 \cdot 7 \\
(78 \cdot 3)\end{array}$ & $\begin{array}{c}24 \cdot 9 \\
(76 \cdot 8)\end{array}$ & $\begin{array}{c}24 \cdot 1 \\
(75 \cdot 4)\end{array}$ & $\begin{array}{c}40 \cdot 7 \\
(\operatorname{ros} \cdot 3)\end{array}$ & $\begin{array}{c}40 \cdot 4 \\
(104 \cdot 7)\end{array}$ & $\begin{array}{c}40 \cdot 4 \\
(104 \cdot 7)\end{array}$ & 30 & 28 & 26 \\
\hline
\end{tabular}

'Temperatures in degrees Fahrenheit are shown in parentheses.

Physiological Data Total sweat loss was measured by weighing the subject nude before and after each test. The pulse rate was counted at the wrist. Skin temperature was measured by 36 thermocouples distributed over the subject's head, body, and limbs. Twelve thermocouples were placed on the chest and back, while the upper arm, wrist, thigh, calf, ankle, and forehead each had four.

During the cooled suit tests, the temperature and humidity of the air leaving the suit were measured using a small psychrometer (Christie et al., 1957). Humidity was not measured in the uncooled suit as the enclosed air became saturated within 20 seconds.

Rectal temperatures were not measured in these trials. Our experience, confirmed by Leithead and Lind (1964), is that under conditions of high stress, rectal temperatures change only slowly due to the insulating effect of surrounding tissue.

\section{Results and Discussion}

Figures 3 and 4 compare the levels of stress in the three clothing assemblies and show the expected peaks during exercise and troughs during rest. In spite of good motivation, the subject was unable to complete trials in the uncooled suit but was forced to retire after 25 minutes. Nevertheless he far exceeded the limits suggested by Robinson and Belding (1948) in their discussions on impermeable clothing.
Based on sweat loss the performance in the cooled suit $(0.75 \mathrm{~kg} . / \mathrm{hr} ; \mathrm{r} .65 \mathrm{lb}$. $/ \mathrm{hr})$ was close to that in shorts $(0.74 \mathrm{~kg}$. $/ \mathrm{hr} ; \mathrm{I} .63 \mathrm{lb} . / \mathrm{hr})$, whereas in the uncooled suit the sweat rate was much higher $(0.99 \mathrm{~kg} . / \mathrm{hr} ; 2.19 \mathrm{lb} . / \mathrm{hr}$ ). The pulse rate (Fig. 3) of the subject in the cooled suit lay between the figure for shorts and that for the uncooled suit which could be worn only for about 25 minutes. However, skin temperature (Fig. 4) was lowest when the operator was wearing the cooled suit due to the effect of cool air passing over the body. The distribution was effective; there was no evidence of excessively cold spots either where tubes touched the body or where the air was released. Further, the cooling air was being used efficiently; when released at the wrists and ankles it was quite dry, but when leaving the suit its moisture content, as shown in Fig. 5, was close to $90 \%$ saturation. The comparatively high temperature of this air was due partly to heat leaking in through the suit material. The mean skin temperature in this assembly is below $33^{\circ} \mathrm{C}$. $\left(9 \mathrm{r} \cdot 4^{\circ} \mathrm{F}\right.$ ), which corresponds to an operative temperature between $27^{\circ} \mathrm{C}$. and $29^{\circ} \mathrm{C}$. $\left(80 \cdot 6^{\circ} \mathrm{F}\right.$.$84 \cdot 2^{\circ} \mathrm{F}$.), i.e., below the zone of evaporative cooling (Winslow and Herrington, 1949). This is another advantage of this form of air-conditioning; the operator is working in a local climate which will remove much of his body heat by convection. Fatigue will be less so no rest period should be needed when work in the suit is completed. 


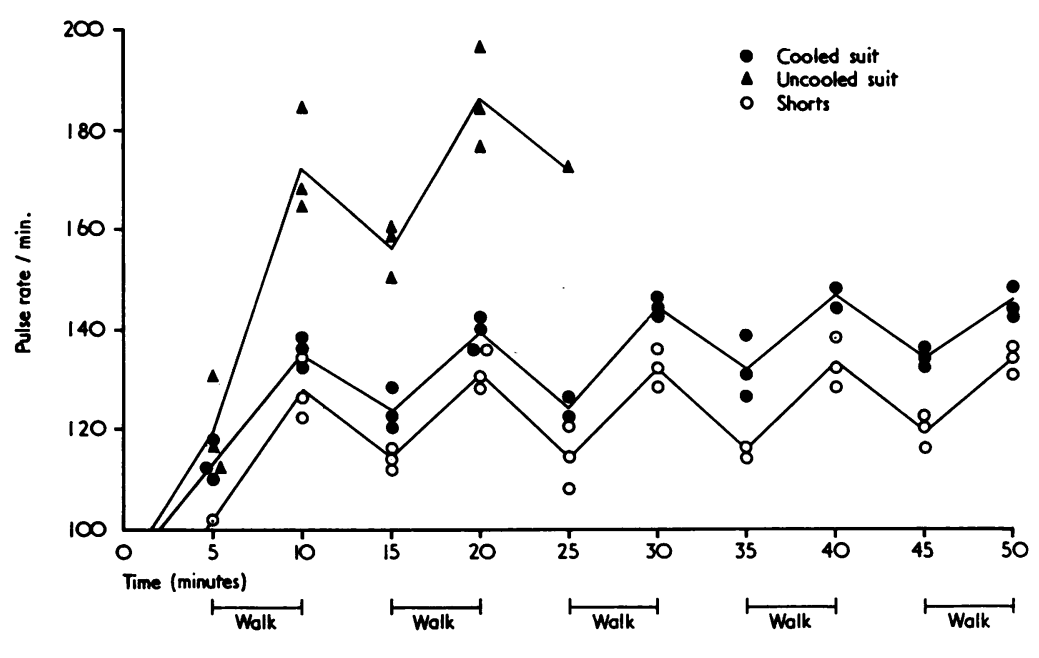

Fig. 3. Pulse rate.

FIG. 4. Skin temperature.

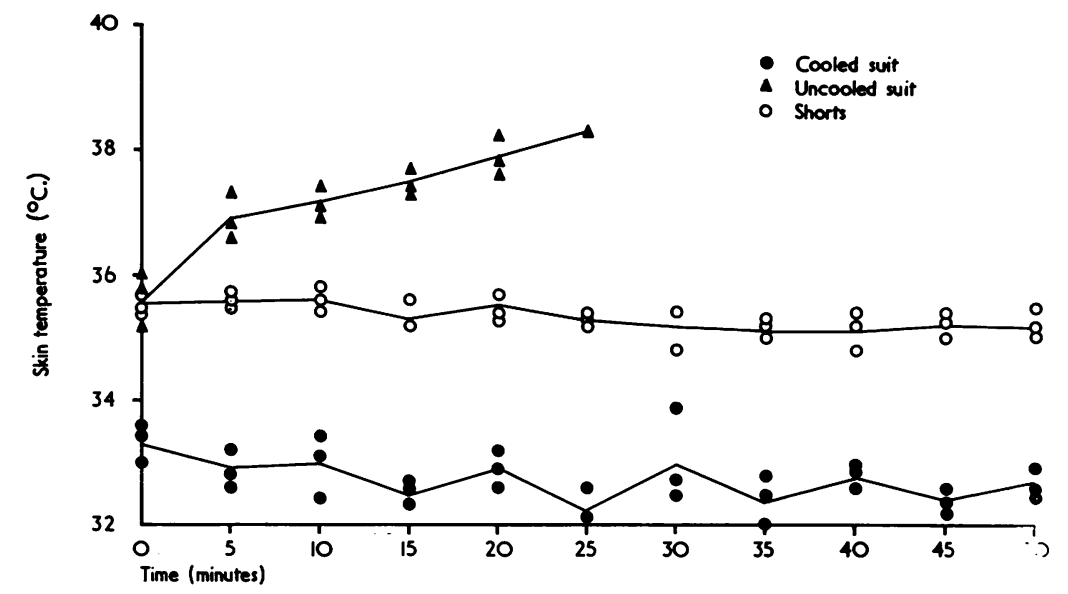

With an endurance time of $50 \mathrm{~min}$. at $40 \cdot 6^{\circ} \mathrm{C}$. ( $105^{\circ} \mathrm{F}$.), the coverall will cope with many industrial situations such as those met in ships' holds, in decontamination work, etc. The tank can readily be topped up or refilled, permitting longer periods of work in the hot environment.

The coverall described was a prototype, constructed to evaluate the practicability of the concept. It is intended to improve its weight and comfort, further lowering the heat stress. The tank will be of aluminium shaped to the wearer's back. The outer surface of the suit will be aluminized and the inner one lined (Crockford and Hellon, 1964). Consideration is being given to replacing the ducting system by a perforated inner lining so that air is released at many points directly on to the body.
With these changes the suit would provide not only a comfortable local environment but also a protective thermal barrier and so would be effective against much higher temperatures.

Future work will aim at finding the upper limit at which the suit can protect an operator for a useful working period.

This paper is published by permission of the Chief Scientist, Australian Defence Scientific Service, Department of Supply, Melbourne, Victoria, Australia.

\section{Note}

Preliminary accounts of this work have appeared in the Australian Defence Standards Laboratories Annual Report, 1964-1965 and in the New Scientist (1965), 28, 727. 

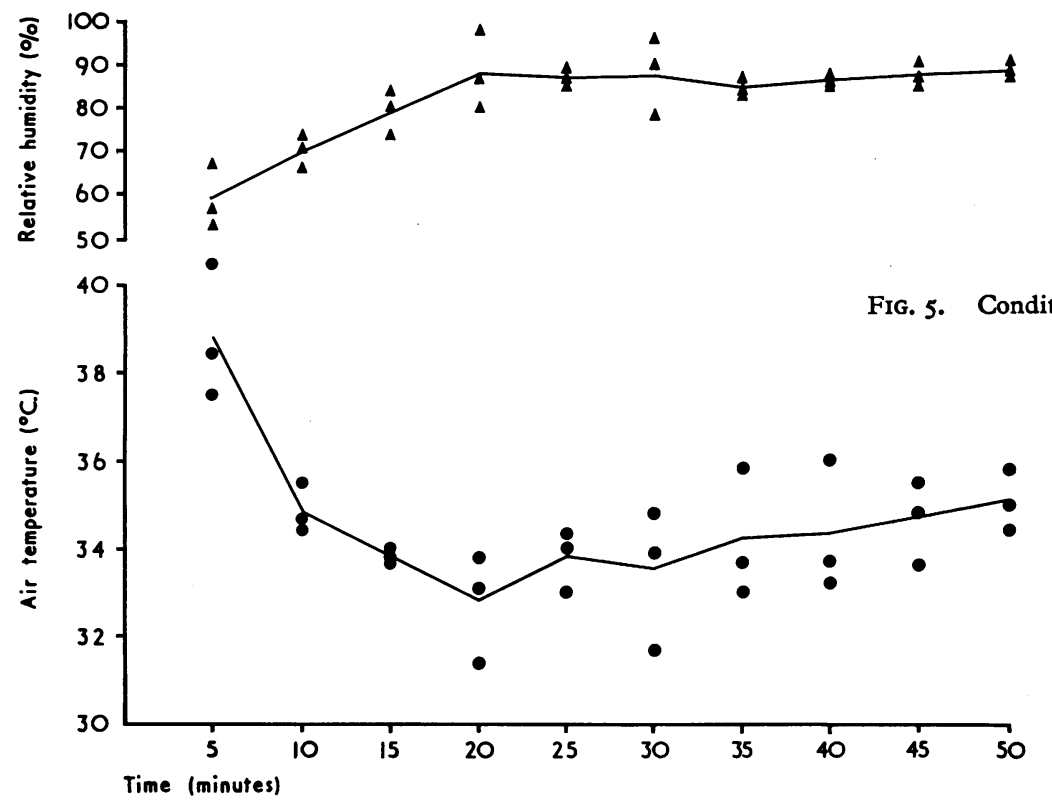

REFERENCES

Anon. (1965). Australian Defence Standards Laboratories Annual Report, 1964-65. See also New Scientist, 28, 727.

Burton, D. R. (1965). Ministry of Aviation, R.A.E. Technical Report 65263.

Christie, G. S., Gleeson, J. P., Jowett, W. G., and Wright, A.S. (1957). Brit. $\mathcal{f}$. industr. Med., 14, 258.

Crockford, G. W., and Hellon, R. F. (1964). Ibid., 21, 187.

Crowden, G. P. (1938). F. roy. Army med. Cps., 70, 145, 217.
Gleeson, J. P. (I96I). AUS. 9. Seventh Commonwealth Defence Conference on Clothing and General Stores, United Kingdom.

- , and Hicks, G. W. (1963). Ministry of Aviation, Brit. Patent 928,537.

Leithead, C. S., and Lind, A. R. (1964). Heat Stress and Heat Disorders, p. 55. Cassell, London.

Robinson, S., and Belding, H. S. (1948). In Advances in Military Medicine, ed. E. C. Andrus and others, Vol. 2, p. 497. Little, Brown, Boston.

Winslow, C. E. A., and Herrington, L. P. (1949). Temperature and Human Life, p. 79. Princeton University Press.

\section{APPENDIX}

When an uncooled sealed suit is worn at $35^{\circ} \mathrm{C}$., i.e., in the zone of evaporative regulation, almost all body heat is lost by sweating. As skin temperature will be close to $35^{\circ} \mathrm{C}$., convection and radiation may be ignored. If the operator is performing light work the metabolic rate will be about $250 \mathrm{kcal}$. per hour. The air space in the suit when worn is about 301 , which at $100 \% \mathbf{R H}$ would hold about $\mathrm{r} \cdot 3 \mathrm{~g}$. of water. As the sweat rate at $35^{\circ} \mathrm{C}$. is of the order of several hundred grams per hour, the suit space would be saturated within seconds. Heat storage would then raise the body temperature by about $4^{\circ} \mathrm{C}$. $\left(\sim 8^{\circ} \mathrm{F}\right.$. $)$ an hour which would cause heat collapse in less than an hour. Therefore some method of cooling or drying of the air within the suit space is needed.

Consider next an impermeable suit fed with air at ambient temperature. Again assume that metabolic heat will be $250 \mathrm{kcal}$. per hour. Then heat removed by sweat evaporation,

$$
\text { where } \begin{aligned}
Q & =m L_{w} \\
Q & =\text { heat removed } \\
m & =\text { mass of water evaporated } \\
L_{w} & =\text { latent heat of vaporization of water. } \\
\text { If } m_{1} & =\text { mass of water per litre of air entering the } \\
& \text { suit }
\end{aligned}
$$

and $m_{2}=$ mass of water per litre of air leaving the suit and $v=$ litres of air per hour through the suit

then $Q=\left(m_{2}-m_{1}\right) L_{w} v$

$$
\therefore v=\frac{250,000}{\left(m_{2}-m_{1}\right) L_{w}}
$$

If the air is supplied at $35^{\circ} \mathrm{C}$. and $40 \% \mathbf{R H}$ and leaves the suit at $35^{\circ} \mathrm{C}$. and $90 \% \mathrm{RH}$, then 
$m_{2}=0.0357 \mathrm{~g} . / 1$. and $m_{1}=0.0158 \mathrm{~g} . / 1$.

and $L_{w}=575 \mathrm{cal} . / \mathrm{g}$.

$$
\begin{aligned}
\therefore \quad v & =\frac{250,000}{(0.0357-0.0158) 575} \\
& =21,9001 . / \mathrm{hr} . \\
& =3641 . / \mathrm{min} \text {. or } 12.8 \mathrm{ft}^{3} / \mathrm{min} .
\end{aligned}
$$

If, however, the air is dried before being supplied to the suit $m_{1}=0$

$$
\begin{aligned}
v & =\frac{250,000}{0.0357 \times 575} \times \frac{\mathrm{I}}{60} \\
& =2031 . / \mathrm{min} . \text { or } 7.2 \mathrm{ft}^{3} / \mathrm{min} .
\end{aligned}
$$

These agree well with experimental results (Christie et al., 1957).

Finally, consider a sealed suit worn with a cooling unit containing liquid air.

Here heat is removed in three ways, viz., (1) evaporation of liquid air, (2) warming of vaporized air to body temperature, and (3) evaporation of sweat by warmed dry air.

where $\begin{aligned} Q & =m_{a} L_{a}+m_{a} C_{p}\left(t_{2}-t_{1}\right)+m_{a} L \text { heat removed }(250 \mathrm{kcal} . / \mathrm{hr})\end{aligned}$

$$
m_{a}=\text { mass of air }
$$

$L_{a}=$ latent heat of vaporization of liquid air (50.97 cal./g.)

$C_{p}=$ specific heat of air at constant pressure (0.24 cal. $/$ g. $/{ }^{\circ} \mathrm{C}$.)

$t_{1}=$ boiling point of liquid air $\left(-192^{\circ} \mathrm{C}\right.$.)

$t_{2}=$ temperature of air leaving suit $\left(+35^{\circ} \mathrm{C}\right.$.)

$L_{w}=$ latent heat of vaporization of water ( $575 \mathrm{cal} . / \mathrm{g}$.

$m_{w}=$ mass of water per gram of air leaving suit (0.0366 g.)

Mass of liquid air per hour to remove $250 \mathrm{kcal}$.

$$
\begin{aligned}
m_{a} & =\frac{250,000}{L_{a}+C_{p}\left(t_{2}-t_{1}\right)+L_{w} \cdot m_{w}} \\
& =\frac{250,000}{50.97+(0.24 \times 227)+(575 \times 0.0366)} \\
& =\mathrm{r} \cdot 976 \mathrm{~kg} . \\
& =4.4 \mathrm{lb} .
\end{aligned}
$$

Therefore a tank holding four to five pounds of liquid air should provide cooling for about an hour. If heat leakage through the suit material was slight, the unit should operate for almost an hour at much higher temperatures. 